\title{
L'officina profumo-farmaceutica di Santa Maria Novella. Dalla nuvola di punti alla realtà virtuale
}

\author{
Federico Cioli \\ Ylenia Ricci
}

Abstract

L'interazione tra il rilievo digitale e i sistemi di Augmented e Virtual Reality offrono ampie possibilità per lo sviluppo di strumenti di disseminazione dei dati raccolti durante le ricerche che hanno per oggetto il Patrimonio. L'integrazione delle nuvole di punti derivanti da rilievi laser-scanner 3D e SfM-IM per lo sviluppo e la creazione di ambienti virtuali riduce ovviamente i tempi di modellazione e di mappatura delle superfici. Il contributo illustra le fasi preliminari di uno studio condotto sull'Officina Profumo-Farmaceutica di Santa Maria Novella, storica farmacia situata nel centro di Firenze. La nuvola di punti prodotta durante le campagne di rilievo digitale laser-scanner 3D, opportunamente ottimizzata, è stata utilizzata come supporto per sperimentare l'utilizzo del modello tridimensionale in ambiente virtuale tramite il software Unreal Engine, dell'azienda produttrice Epic Games, ed in particolare del plug-in Lidar Point Cloud. La finalità del presente contributo è quella di illustrare le fasi preliminari per l'istituzione di un virtual tour nel quale vengono inseriti e resi accessibili i risultati della ricerca e contenuti di interesse attraverso un'interfaccia interattiva di facile utilizzo, sfruttando le potenzialità descrittive proprie della nuvola di punti.

Parole chiave

rilievo digitale, VR, centro storico di Firenze patrimonio UNESCO.

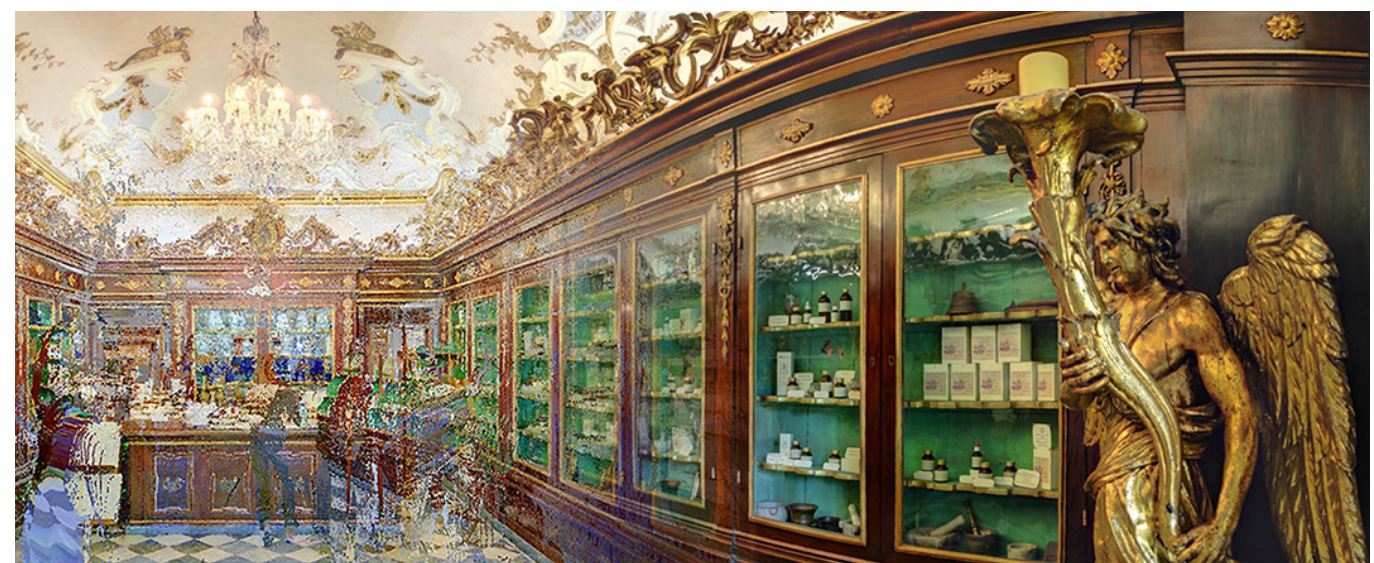




\section{Introduzione}

Lo sviluppo tecnologico [I] nell'ambito del rilievo digitale consente la realizzazione di elaborati sempre più descrittivi che uniti alle innovazioni nel campo videoludico e delle tecnologie di Augmented e Virtual Reality (AR e VR) possono essere utilizzati per sviluppare strumenti di fruizione delle informazioni e dei dati raccolti durante le ricerche sul Patrimonio. II caso studio dell'Officina Profumo-Farmaceutica di Santa Maria Novella rientra all'interno di un progetto di ricerca per la documentazione delle Attività Economiche Storiche eTradizionali Fiorentine intrapreso nel 2017 dall'Università di Firenze in collaborazione con il Comune di Firenze e l'ufficio Firenze Patrimonio Mondiale e tuttora in corso [Bertocci, Cioli, Bordini 20 I 8]. Alcuni dei negozi storici analizzati sono stati selezionati per il loro valore architettonico ed artistico e sono stati oggetto di campagne di rilievo laser-scanner 3D e Structure from Motion Image Matching (SfM-IM). La fase di acquisizione dei dati ha previsto la pianificazione di un numero elevato di scansioni, alcune delle quali sovrapposte a diversa quota, che consentissero di evitare le formazioni di coni d'ombra sulle superfici e che tenessero in considerazione anche gli arredi e gli oggetti. L'utilizzo di un laser-scanner Z+F 5016 ha consentito, attraverso la camera integrata, di istituire una nuvola di punti integrata da immagini ad alta risoluzione ben bilanciate nella rappresentazione del colore originale degli elementi e quindi altamente descrittiva, che ha richiesto un processo di post-produzione e pulizia del dato al fine di rimuovere le parti di nuvola di punti generata in maniera impropria, a causa delle superfici lucide, riflettenti, traslucide e trasparenti, che spesso sono presenti proprio in questi ambienti destinati all'esposizione delle merci. Le basi ottimizzate così prodotte sono state quindi utilizzate per una prima realizzazione di elaborati 2D, compatibili con le procedure tradizionali per la valutazione e la gestione del Patrimonio Costruito. La parte principale del progetto di documentazione ha previsto la restituzione dei tradizionali elaborati 2D rappresentanti piante e sezioni alla scala di dettaglio, comportando un impegnativo processo di ridisegno e discretizzazione del dato; tutto ciò ha quindi fatto emergere la necessità di rendere fruibile anche il dato tridimensionale, che opportunamente ottimizzato, può essere utilizzato come modello per generare anche una visita virtuale all'interno dell'attività commerciale. Negli ultimi anni, l'industria dei videogame ha iniziato ad integrare le nuvole di punti nelle scene al fine di evitare i lunghi processi di modellazione degli ambienti virtuali. Partendo da questo presupposto e dallo sviluppo di nuovi software e plug-in che mettono in relazione le discipline del remote sensing con l'istituzione di strumenti virtuali è nata la collaborazione tra il Laboratorio di Rilievo dell'Architettura (LRA) e il Laboratorio di Extended Reality (LXR) del DIDA - Dipartimento di Architettura dell'Università di Firenze, applicata al caso studio dell'Officina Profumo-Farmaceutica di Santa Maria Novella a Firenze, ritenuta la farmacia più antica d'Europa.

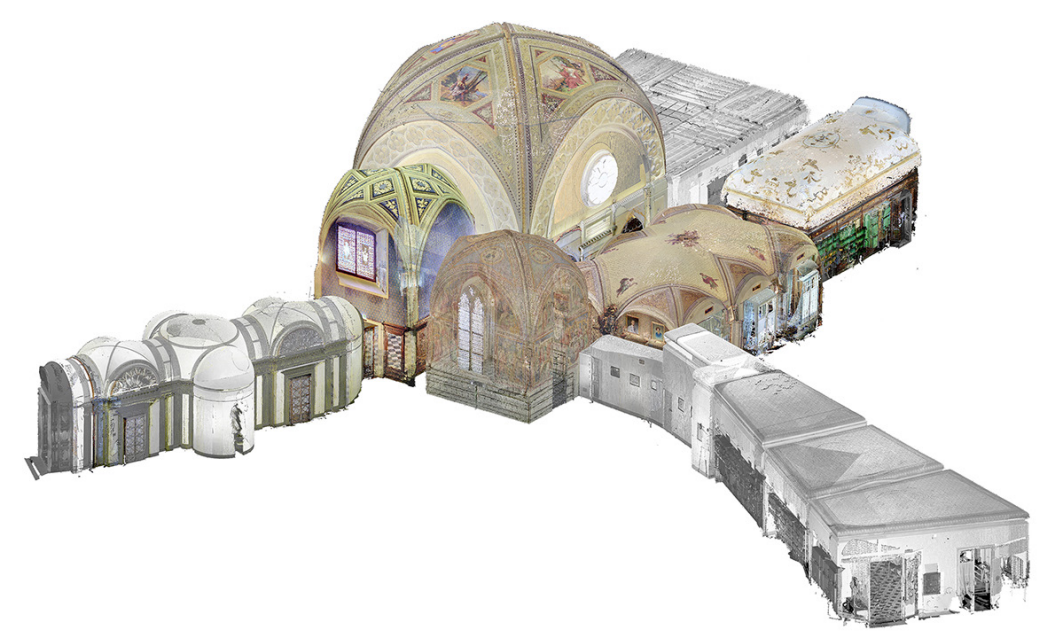




\section{L'evoluzione storico-architettonica dell'officina}

L'officina Profumo-Farmaceutica di Santa Maria Novella venne fondata nel 1612 [Alphandery, Ciappi 2017, pag. 29] ed è la sintesi di una secolare evoluzione di una serie di ambienti strettamente connessi al famoso complesso monastico omonimo e alla storia della città. Situata nel luogo dove dal XIII secolo era presente l'officina aromataria del convento domenicano, la farmacia si inserisce all'interno della monumentale cappella di San Niccolò, costruita tra il 1332 e il 1334, grazie ad un generoso finanziamento di Dardano di Tingo Acciaioli, stanziato per gratitudine nei confronti dei frati domenicani che lo avevano guarito [Alphandery, Ciappi 20 17, pag. I 2]. Tra il I 385 e il I 405 la stessa famiglia Acciaioli finanziò gli affreschi della sagrestia con le scene della Passione di Cristo attribuiti a Mariotto di Nardo [Alphandery, Ciappi 2017, pag. 14]. Nel Settecento vennero rinnovati i locali dell'antica spezieria, affacciati sul chiostro grande, con la decorazione della volta in stile rocaille e la realizzazione di un fregio decorativo per smorzare l'austerità dell'arredo parietale e del bancone e per richiamare gli stucchi dorati rappresentanti figure grottesche del soffitto. La Sala Verde, annessa alla farmacia nel 1542 come laboratorio, venne trasformata in sala per il ricevimento di ospiti di riguardo e arredata in stile direttorio. In questa sala sono contenuti i ritratti dei frati direttori, a partire da Angelo Marchisi, che aprì l'attività al pubblico nel 16I2. Nel ritratto dello speziale Tommaso Valori (I756- |825) [2], che nel I 8 I3 acquistò la spezieria dal governo francese, si trova la planimetria della farmacia. Egli infatti sviluppò un progetto per la trasformazione della cappella di San Niccolò da magazzino a sala vendite e per la realizzazione di un nuovo ingresso più ampio su via della Scala. Nel I8|4, con la revoca della soppressione dei beni ecclesiastici imposta dal governo napoleonico la chiesa e il convento di Santa Maria Novella tornarono ai frati e nel 1817 Valori donò la spezieria ai padri domenicani, mantenendone però la direzione fino al | 823. II progetto sviluppato da Valori venne attuato dal suo successore, il nuovo speziale fra' Damiano Beni (I 806- I869), che iniziò i lavori nel 1847, sotto la direzione dell'architetto Enrico Romoli [Alphandery, Ciappi 2017, pag. 63]. II progetto prevedeva una ridistribuzione radicale degli ambienti interni, chiudendo l'ingresso dal chiostro, dividendo le campate della cappella di San Niccolò in due vani distinti e fondendo allo stile gotico e rococò della farmacia, quello neoclassico e neogotico dei nuovi ambienti [3]. Dal nuovo ingresso in stile neoclassico (fig. 3), costituito da un atrio con scalinata con decorazioni di ordine ionico in pietra serena, si accede ad un ambiente voltato a crociera che funge da atrio di ingresso alla sala vendite in stile neogotico, affrescato da Paolino Sarti con motivi rappresentanti i quattro continenti a sottolineare l'importanza internazionale della farmacia e la provenienza esotica delle materie prime [4].

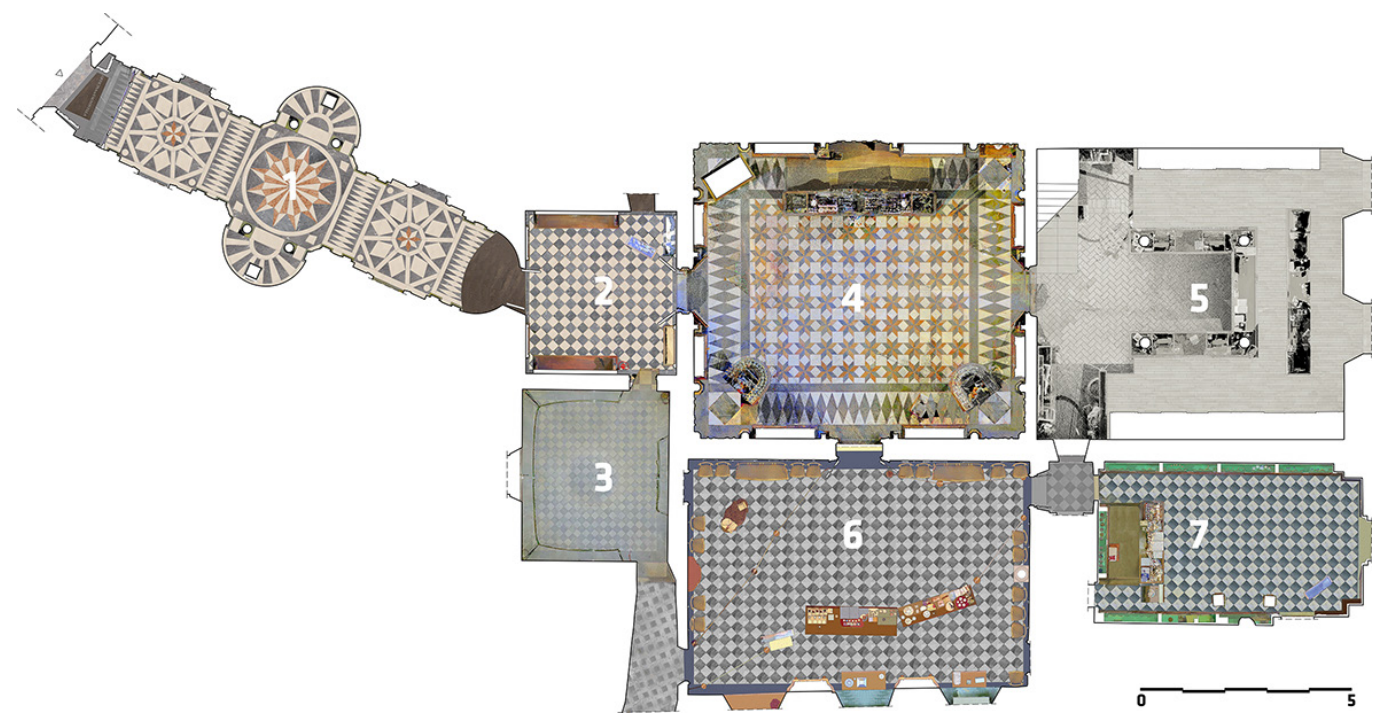


L'Officina, così come appare al giorno d'oggi, è il risultato di un importante intervento di restauro avvenuto nel 20 I2. Le due campagne di rilievo laser-scanner, realizzate nel 2019 e nel 2020, hanno prodotto una nuvola di punti a colori dell'intero complesso farmaceutico, ma al fine dello sviluppo del tour virtuale sono stati presi in considerazione solamente gli ambienti trattati in questo paragrafo.

Fig. 3. Sezione longitudinale degli ambienti 1, 2, 4 e 5 . Gli elaborati 2D sono stat realizzati durante il corso di Rilievo dell'Architettura di Rilievo dellArchitettura del prof. Stefano Bertocci. Si ringraziano gli studenti: Sara Bertoncini, Sara Biagini, Elisa Bianucci, Chiara Bovagnet, Francesco Capacci, Bianca Sofia Cardelli, Irene Cardelli,Valeria Chiariello, Romina Columbu, Michele Di Puorto, Marco Duranti, Sara Marchesini, Francesca Muzzi.

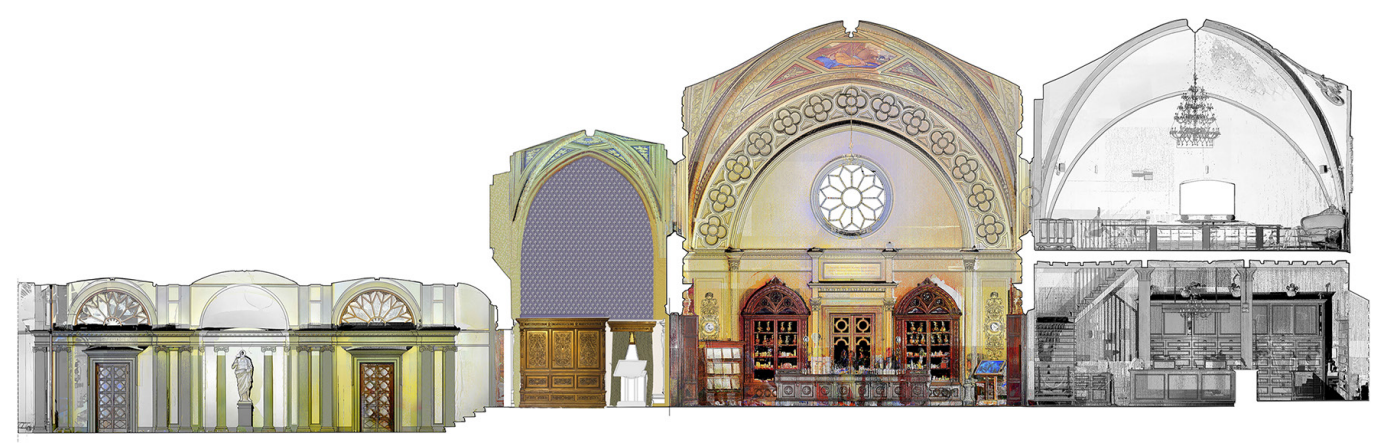

\section{La virtualizzazione della nuvola dei punti}

II fine della realtà virtuale è quello di simulare un ambiente reale per mezzo di nuove tecnologie fino a dare a chi la sperimenta l'impressione di trovarsi realmente immerso in quel contesto. Oggi il termine ha assunto anche un significato più ampio e indica tutte quelle applicazioni che consentono un qualche grado di interazione con l'ambiente descritto, anche quando la simulazione non è totale ma coinvolge solo alcuni sensi. L'idea della creazione di ambienti artificiali non è di per sé legata al mondo dell'architettura, fu infatti sperimentata per la prima volta nel 1962 con il Sensorama, un apparecchio meccanico ideato da M. Heilig che mirava a coinvolgere non solo la vista e l'udito, ma anche l'olfatto e il tatto di uno spettatore che osservava i filmati appositamente realizzati per quella macchina. La realtà virtuale qui trattata nasce per dare la possibilità di creare scenari e paesaggi tridimensionali all'interno dei quali un soggetto ha l'impressione di muoversi; lo scopo di questa ricerca è quello di virtualizzare l'ambiente rilevato in modo da creare nuove opportunità e nuovi strumenti di studio e di conoscenza del patrimonio costruito. Attraverso le visite virtuali interattive, viene fornito al visitatore un quadro quanto più possibile completo dell'edificio e si propone all'utente un'esperienza formativa personalizzata in cui è egli stesso a scegliere cosa visualizzare e quali informazioni estrarre in base ai suoi interessi personali, si richiede infatti una partecipazione attiva dell'utente. Con le tecnologie attualmente disponibili la fruizione delle visite virtuali interattive può avvenire in molteplici modi. Realizzare un ambiente virtuale non è però un'operazione facile $\mathrm{o}$ istantanea e richiede tempo, precisione e specifiche competenze tecniche. Per la realizzazione di questo ambiente virtuale è stato quindi utilizzato il software Unreal Engine, prodotto dalla Epic Games, per riportare in un alternativo ambiente virtuale la Farmacia di SMN e per offrire un format che possa essere riutilizzato in qualsiasi altro contesto affine. Unreal Engine è uno dei più affermati software Open Source sul mercato per la creazione di Real Time Rendering e ambienti virtuali, in continuo sviluppo non solo per assolvere le originarie funzioni legate al mondo del gaming, ma oggi in grado di offrire le più dettagliate esperienze virtuali. Attualmente è disponibile la quarta generazione del motore, UE4, versione 4.24.2. L'iter svolto solitamente per poter utilizzare il software è quello di esportare i modelli in formato.FBX da Maxon Cinema 4D o da altri software di modellazione 3D e di importarli all'interno del Content, dopo un passaggio intermedio di ottimizzazione dei poligoni e dei punti caratterizzanti il modello che rende più fluida l'esperienza interattiva. Lidar Point Cloud, il nuovo plug-in all'interno di UE4, rivoluziona completamente il workflow fino ad ora seguito per la digitalizzazione e virtualizzazione del 
bene architettonico poiché è stato sviluppato per aiutare gli utenti a importare, visualizzare ed elaborare nuvole di punti acquisite da dispositivi di scansione laser (fig. 4).

Le caratteristiche principali riguardano i file supportati, cioè ASCII (TXT, XYZ, PTS) e LAS, e la capacità di caricare risorse di grandi dimensioni, riconoscendo le diverse tipologie di colorazione dei punti (come RGB, Intensità, Elevazione, Classificazione) e la possibilità di gestire la nuvola di punti importata in tutta la sua complessità. All'interno del pannello Details della nuvola di punti, il primo step è quello di settare la quantità di punti che vogliamo visualizzare nella scena, ovviamente un numero elevato di punti consente una rappresentazione dell'architettura più veritiera e dettagliata ma comporta un aumento sostanziale del numero di elementi e quindi del successivo tempo di renderizzazione che potrebbe causare un rallentamento anche durante la riproduzione virtuale, a causa del calo degli FPS (frames per second) all'interno della scena, che non dovrebbero essere inferiori a 90 per garantire una piacevole e fluida immersione nel virtuale (fig. 5).

Quando ci avviciniamo ad una Static Mesh che abbiamo posizionato nel livello, nel nostro caso si parla della nuvola stessa, vorremmo che la mesh si presentasse molto dettagliata. Tuttavia, non è necessario che questo livello di dettaglio permanga una volta che ci allontaniamo, se questa occupa solo pochi pixel sullo schermo. UE4 risolve appunto attraverso l'uso dei Level of Details o LODs, il problema della pesantezza della scena causata dal quantitativo di oggetti presenti in essa. Oltre alla quantità di punti, gli step successivi riguardano il settaggio della loro dimensione e forma; risulta quindi evidente che essere in grado di modificare le nuvole di punti all'interno del software di visualizzazione finale senza dover ricorrere all'utilizzo di software specifici come Autodesk Recap o CloudCompare sia un vantaggio enorme in materia di tempistiche e di complessità del workflow (fig. 6). Una volta completati i vari passaggi e creata l'applicazione, la visualizzazione dell'ambiente virtuale avviene attraverso l'utilizzo di visori, come ad esempio Oculus Rift S, Oculus Quest o HTC Vivepro II visore può essere sostituito da un supporto VR per smartphone, che grazie al costo contenuto, lo rende accessibile ad un più ampio pubblico, anche se sensibilmente a discapito della qualità di esperienza proposta.

Fig. 4. II nuovo ingresso presenta due nicchie con le statue di Galeno, medico greco che influenzò la medicina e la scienza farmaceutica fino al Rinascimento, ed Igea, dea della salute e dell'igiene. Le immagini sono state estrapolate da rappresentazioni derivate dalla scansione.
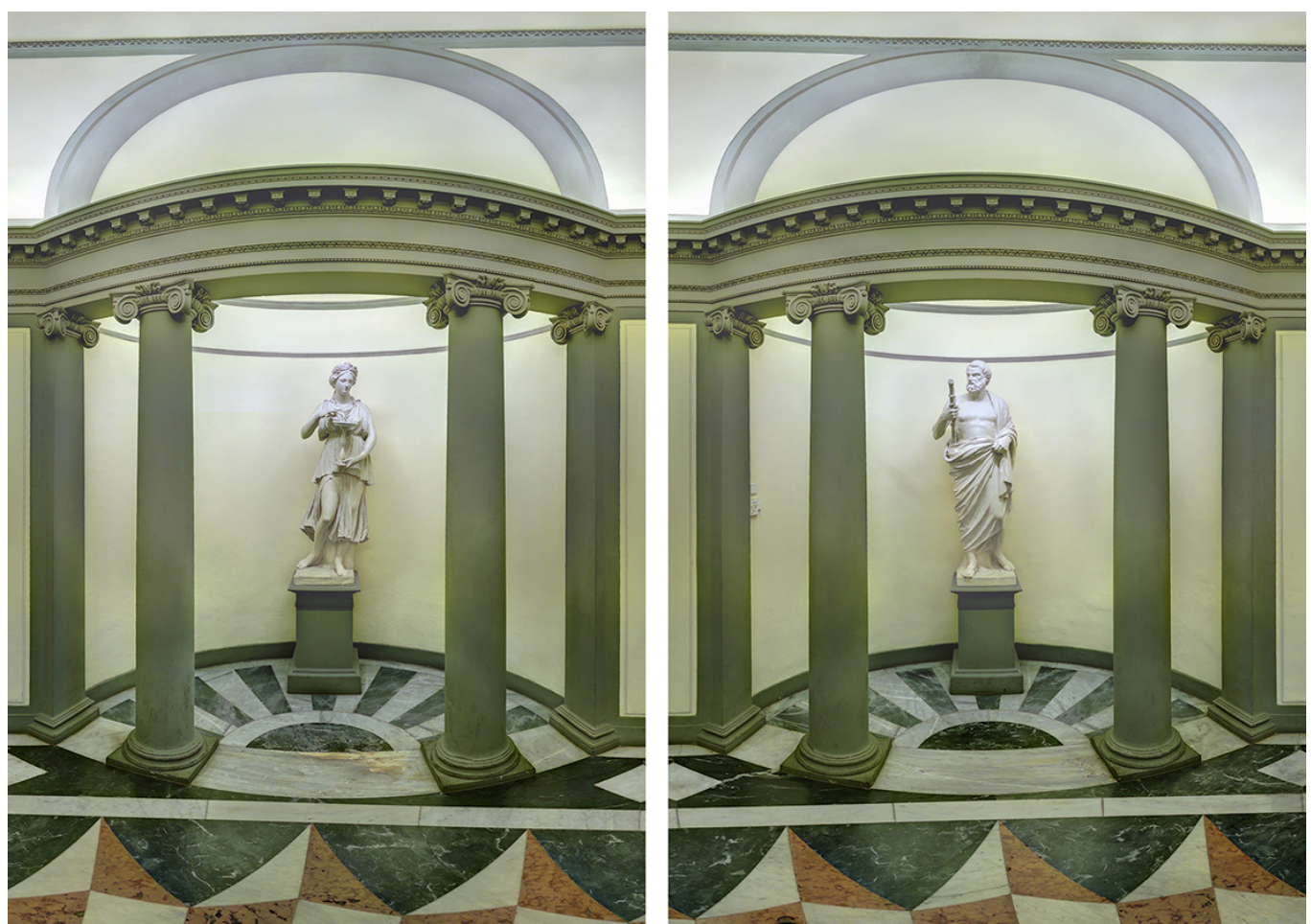
Alla fine della ricerca, vale la pena ricordare che il processo punta a creare un prodotto completo, integrando il dato principale (analisi storica e rilievo del bene architettonico), la semplificazione del processo di virtualizzazione, l'uso dell'esperienza VR nel patrimonio culturale e la creazione di una realtà temporale virtuale. Questo registra le condizioni dell'edificio al momento del rilievo e lo rende accessibile e percepibile in futuro, costituendo un archivio cronologico delle sue condizioni e della sua evoluzione temporale. L'archiviazione del Patrimonio Culturale amplia la possibilità di analisi e studio dell'oggetto con l'aumento sensoriale del rapporto con esso e con l'intento di creare un prototipo, una metodologia applicabile non solo a questo tema, ma a tutto il patrimonio architettonico esistente. I settori della ricerca coinvolti in questo processo di realizzazione di nuovi percorsi esplorativi sono molteplici e gli esiti sono apprezzabili nelle ricostruzioni di paesaggi, città, monumenti e opere d'arte. Si crea un ambiente che diviene luogo dinamico in cui uomo e architettura interagiscono in base a prospettive legate al passato e al presente, si ricreano complessi monumentali nel loro aspetto originario, con interessanti sviluppi nella diagnosi dello stato di degrado e nel restauro e si offre una nuova modalità di indagine e catalogazione del bene architettonico.

Fig. 5. Il vano dell'antica spezieria. La volta in stile rocaille è stata decorata nel Settecento con motivi grotteschi in stucco dorato.

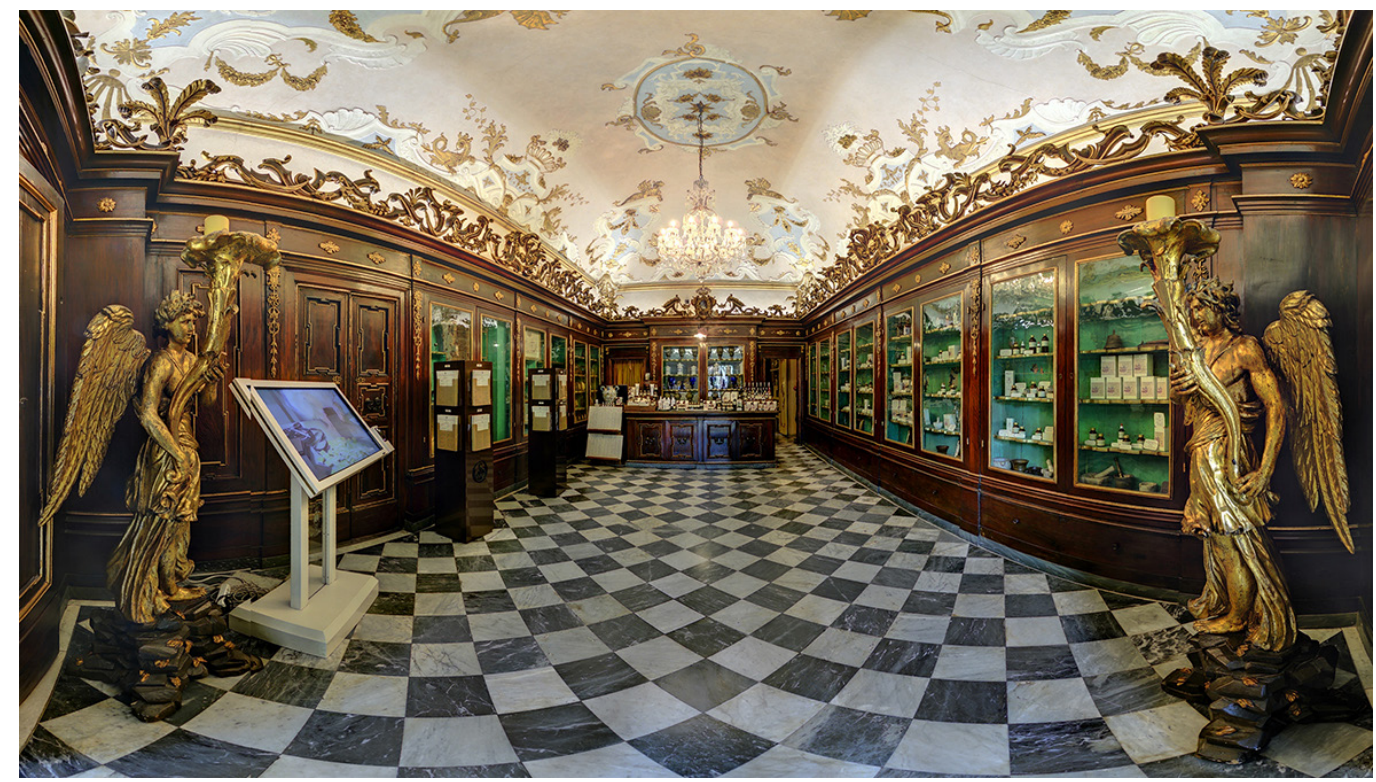

\section{Conclusioni}

La grande quantità di dati fisici e digitali acquisiti durante le campagne di rilievo costituisce un archivio di informazioni che rischia di rimanere inutilizzato. La finalità del presente lavoro è quella di presentare i primi risultati di un processo che mira a sviluppare una metodologia per la gestione e la fruizione delle nuvole di punti, che costituiscono banche dati ricche di informazioni metriche e morfologiche. Attraverso l'istituzione di un virtual tour all'interno del modello 3D è possibile inserire le informazioni storiche e la documentazione raccolte durante la ricerca al fine di sviluppare strumenti di disseminazione dei risultati che comportano un'ottimizzazione nell'utilizzo dei dati senza la necessità di ulteriori fasi di modellazione e rendering. I dati vengono resi attraverso un'interfaccia interattiva di facile utilizzo, sfruttando le potenzialità descrittive della nuvola di punti che di per sé costituisce un importante archivio di dati metrici che nella discretizzazione della rappresentazione 2D necessariamente perde contenuti. Questi strumenti risultano meno accattivanti per l'utente rispetto alle interfacce ottenute mediante modellazione NURBS o mesh, accentuando l'aspetto fun- 


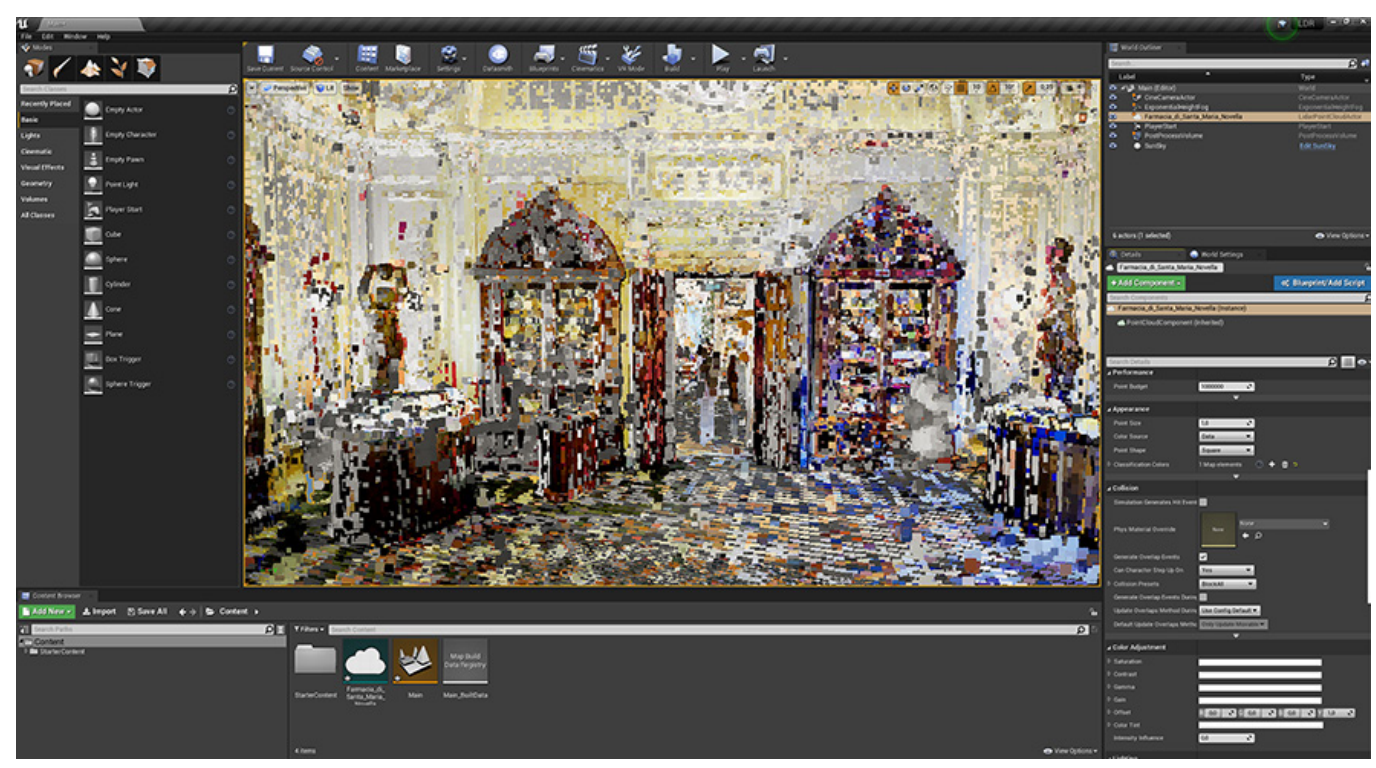

zionale e didattico dei modelli e la necessità di una maggiore affidabilità tra l'oggetto reale e l'ambiente virtuale. II rischio che si corre attraverso la virtualizzazione del patrimonio è quello di attirare l'attenzione di utenti sempre meno critici, infatti l'esperienza virtuale non deve sostituire o imitare l'esperienza reale ma deve essere un'esperienza culturale in sé, che consente di acquisire informazioni altrimenti non accessibili nella realtà fisica.
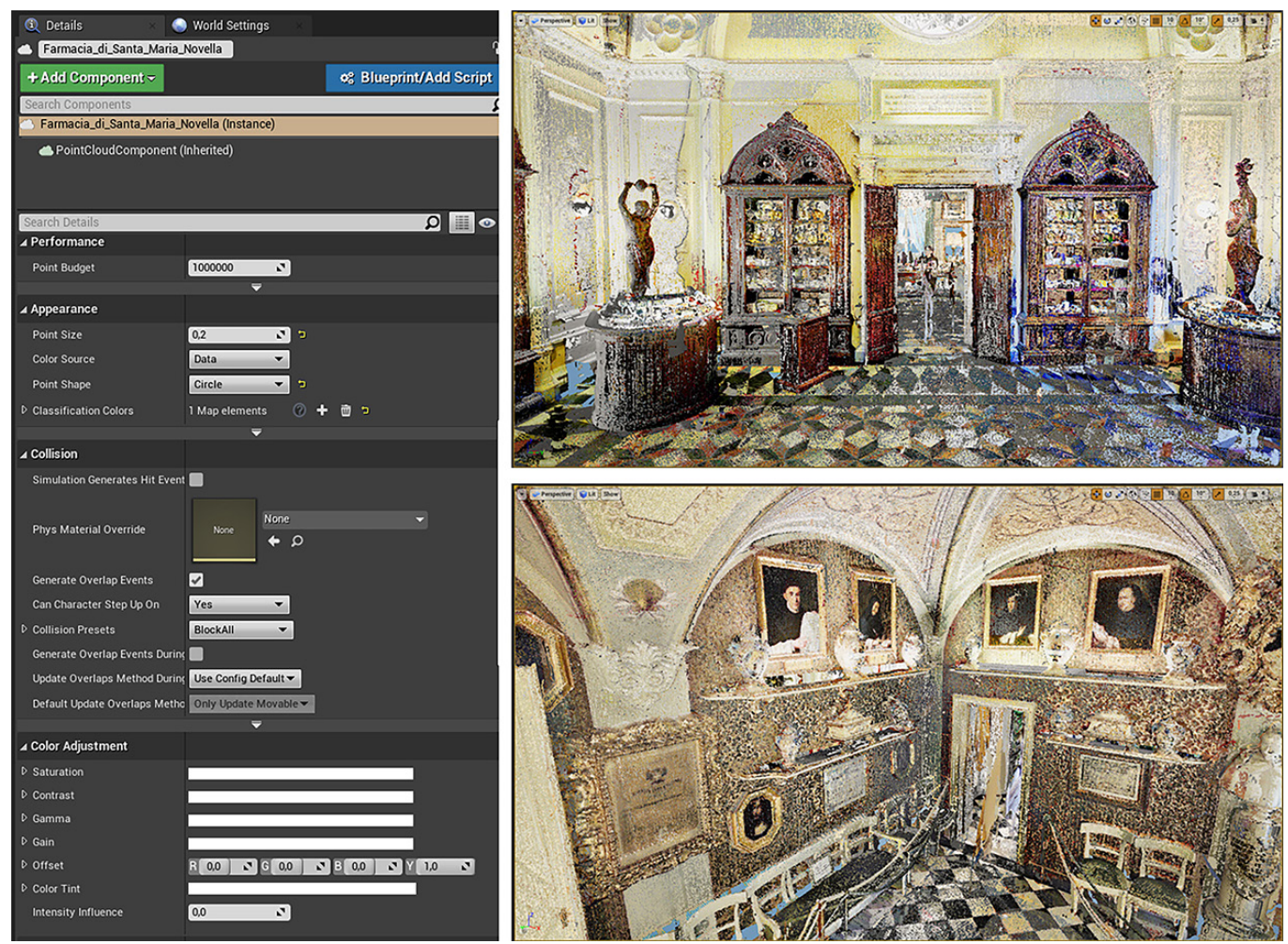

Fig. 7. Sulla sinistra: settaggio delle impostazion Nuvola; sulla destra: la nuvola di punti visualizzata
in Lidar Point Cloud.

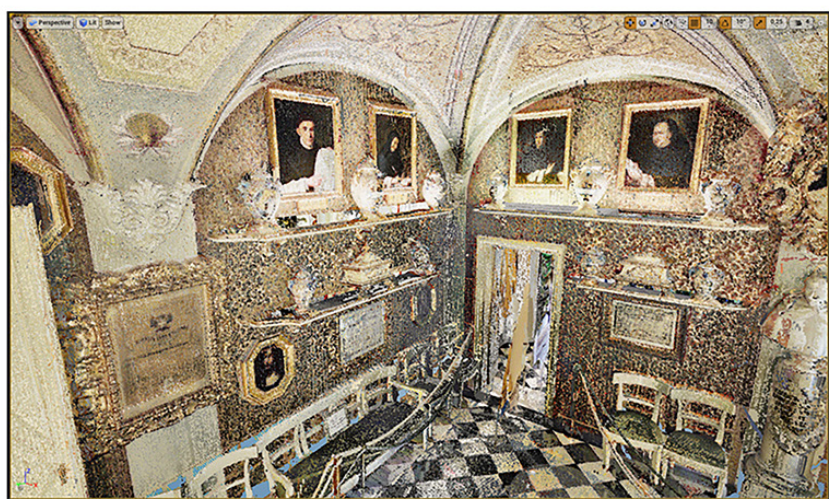




\section{Note}

[I] Si deve a Federico Cioli la redazione dei paragrafi I, 2 e 4. Si deve a Ylenia Ricci la redazione del paragrafo 3.

[2] Riconosciuto come farmacista dall'Arte dei Medici e degli Speziali, Valori si trovò direttore dell'officina nel periodo napoleonico e grazie a lui rimase aperta al pubblico grazie alla valenza scientifica della produzione.

[3] Dello stesso periodo in Italia ritroviamo esempi di questa commistione di stili nella Casa di Ignazio Villa ( 847 ), a Firenze e nel Caffè Pedrocchi (|83|-|839) a Padova.

[4] La posizione dell'attuale bancone, posto sulla sinistra rispetto all'entrata, è quella originale. Infatti il nuovo ingresso venne realizzato successivamente rispetto alla nuova sala vendite, mantenendo l'accesso dal chiostro per alcuni anni.

\section{Riferimenti bibliografici}

Alphandery Benedetta, Ciappi Silvio (20 I7). Officina Profumo Farmaceutica di Santa Maria Novella. Milano: Silvana Editoriale.

Bertocci Stefano, Cioli Federico, Bordini Eugenia (2018). Virtual models for the valorisation and promotion of the business heritage in the historic centre of Florence. In DisegnareCon, Vol I I, No 21.

Cioli Federico (2019). I luoghi del commercio: tra realtà e rappresentazione. In Belardi Paolo (a cura di). Riflessioni. L'arte del disegnolil disegno dell'arte. Atti del $41^{\circ}$ Convegno Internazionale dei Docenti delle Discipline della Rappresentazione. Perugia, 19-2I settembre 2019. Roma: Gangemi Editore, pp. 553-560.

Mancini Gabriella, Giovannini Sandra (1994). L'Officina Profumo-Farmaceutica di Santa Maria Novella in Firenze sette secoli di storia e di arte. Roma: Chitarrini.

Verdiani Giorgio, RicciYlenia, Pasquali Andrea, (2019a). Mito, pietra, spolia e storia, frammenti di indefinito da Costantinopoli a Istanbul. In Conte Antonio, Guida Antonella (a cura di). ReUso. Patrimonio in divenire. Conoscere, valorizzare, abitare. Matera 2019. Roma: Gangemi Editore, pp. 1203-1214.

Verdiani Giorgio, RicciYlenia, Pasquali Andrea, (2019b). Ancient remains from the Roman Istanbul: a transmutation from stone to digital. In C. ten Busch, C. Kassung, J. Sieck (eds.). Proceedings of KUl. Kultur und Informatik: Virtual History and Augmented Present. Glückstadt:WWH Verlag Wemer Hiilsbusch, pp. I5-28.

Verdiani Giorgio, Ricci Ylenia, Pasquali Andrea, (2019c). A petrified petrifying eyesight: a story for the Medusa's heads. In W. Börner, S. Uhlirz (eds.). Proceedings of the 23rd International Conference on Cultural Heritage and New Technologies 20 I8, Wien, pp. I- I5.

\section{Autori}

Federico Cioli, Università di Firenze, federico.cioli@unifi.it Ylenia Ricci, Università di Firenze, ylenia.ricci@unifi.it

Per citare questo capitolo: Cioli Federico, Ricci Ylenia (2020). L'officina profumo-farmaceutica di Santa Maria Novella. Dalla nuvola di punti alla realtà virtuale/L'Officina Profumo-Farmaceutica di Santa Maria Novella. From the point cloud to the virtual reality. In Arena A., Arena M., Brandolino R.G., Colistra D., Ginex G., Mediati D., Nucifora S., Raffa P. (a cura di). Connettere. Un disegno per annodare e tessere. Atti del $42^{\circ}$ Convegno Internazionale dei Docenti delle Discipline della Rappresentazione/Connecting. Drawing for weaving relationships. Proceedings of the 42 th International Conference of Representation Disciplines Teachers. Milano: FrancoAngeli, pp. 1958-1973. 


\title{
L'Officina Profumo-Farmaceutica di Santa Maria Novella. From the Point Cloud to the Virtual Reality
}

\author{
Federico Cioli \\ Ylenia Ricci
}

Abstract

The interaction between the digital survey and the Augmented andVirtual Reality systems offer wide opportunities for the development of tools for disseminating the data collected during research about heritage. The integration of point clouds deriving from 3D laser-scanner and SFM-IM surveys for the development and creation of virtual environments reduces modeling and surface mapping times. The contribution illustrates the preliminary stages of a study conducted on the Pharmacy of Santa Maria Novella, a historic pharmacy located in the center of Florence. The point cloud generated during the digital laser-scanner survey campaigns, appropriately optimized, was used as a support to experiment the use of the three-dimensional model in a virtual environment through the Unreal Engine software, from the manufacturer Epic Games, and in detail of the Lidar Point Cloud plug-in. The purpose of this contribution is to illustrate the preliminary phases for the establishment of a virtual tour in which the results of the research and contents of interest are inserted and made accessible through an easy-to-use interactive interface, exploiting the descriptive potential of the point cloud.

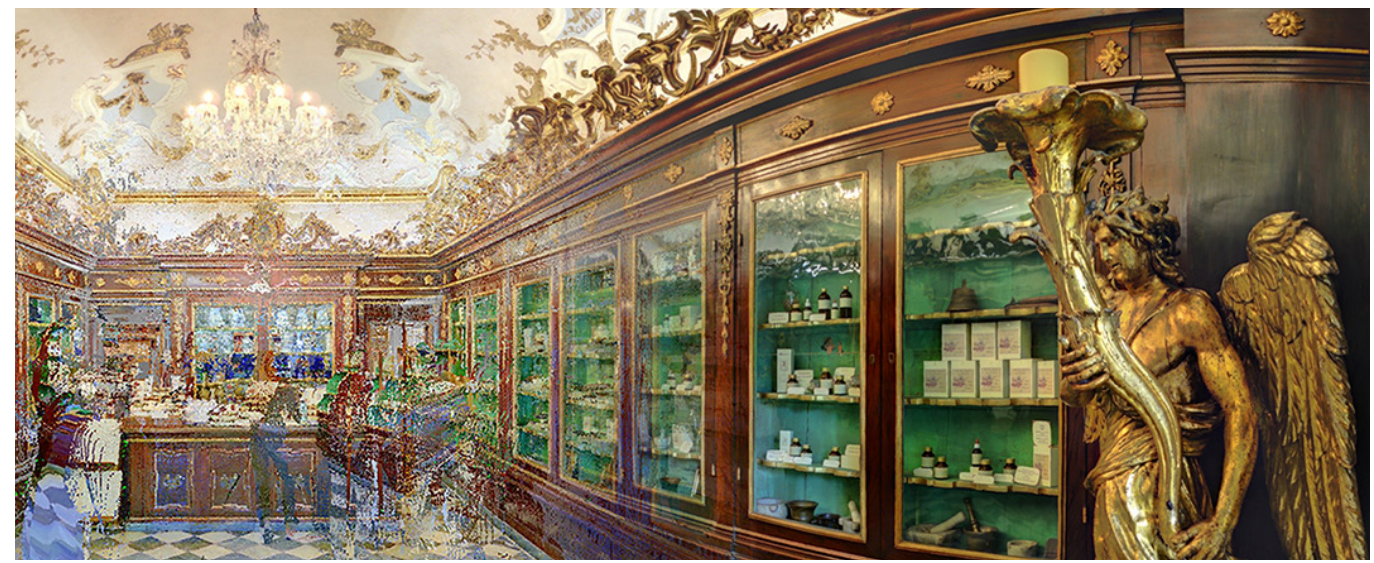




\section{Introduction}

Technological development [I] in the field of digital surveying allows the creation of increasingly descriptive data which, combined with innovations in the gaming field and Augmented and Virtual Reality (AR and VR) technologies, can be used to develop tools for using the information collected during the research concerning the Heritage. The case study of the Pharmacy of Santa Maria Novella is part of a research project for the documentation of Florentine Historical and Traditional Shops undertaken in 2017 by the University of Florence in collaboration with the Municipality of Florence and the Florence World Heritage office and still ongoing [Bertocci, Cioli, Bordini 2018]. Some of the historical shops have been selected for their architectural and artistic value and have been the subject of 3D laser-scanner and Structure from Motion Image Matching (SfM-IM) surveys. The data acquisition required a large number of laser-scanner stations, some of which overlapped at a different height, which allowed to avoid the shadow cones on the surfaces, taking into consideration the furnishings and objects. The use of a Z+F 5016 laser scanner allows to create a highly descriptive colored point cloud trough the integration of high-resolution images with reliable colors. The model required a post-production process and cleaning of the data to remove the parts of point cloud improperly generated, due to the shiny, reflective, translucent, and transparent surfaces, which are often present in these shops. Firstly, the project provides the creation of 2D drawings, compatible with traditional procedures in the evaluation and management of the built heritage. The main part of the documentation project involved the realization of traditional 2D drawings. They concern plans and sections at the scale of detail which require a process of redesigning and discretizing the data.This process highlights the need to make the three-dimensional data usable, which when properly optimized, can be used as a model to generate a virtual visit within the shops.

In recent years, the video game industry has begun to integrate point clouds into scenes to avoid lengthy modeling processes in virtual environments. Starting from this assumption and from the development of new software and plug-ins that relate the disciplines of remote sensing with the institution of virtual instruments, the project led to the collaboration between the Laboratory of Architectural Survey (LRA) and the Laboratory of Extended Reality (LXR) of DIDA - Department of Architecture of the University of Florence, applied to the case study of the Pharmacy of Santa Maria Novella in Florence, considered the oldest pharmacy in Europe.

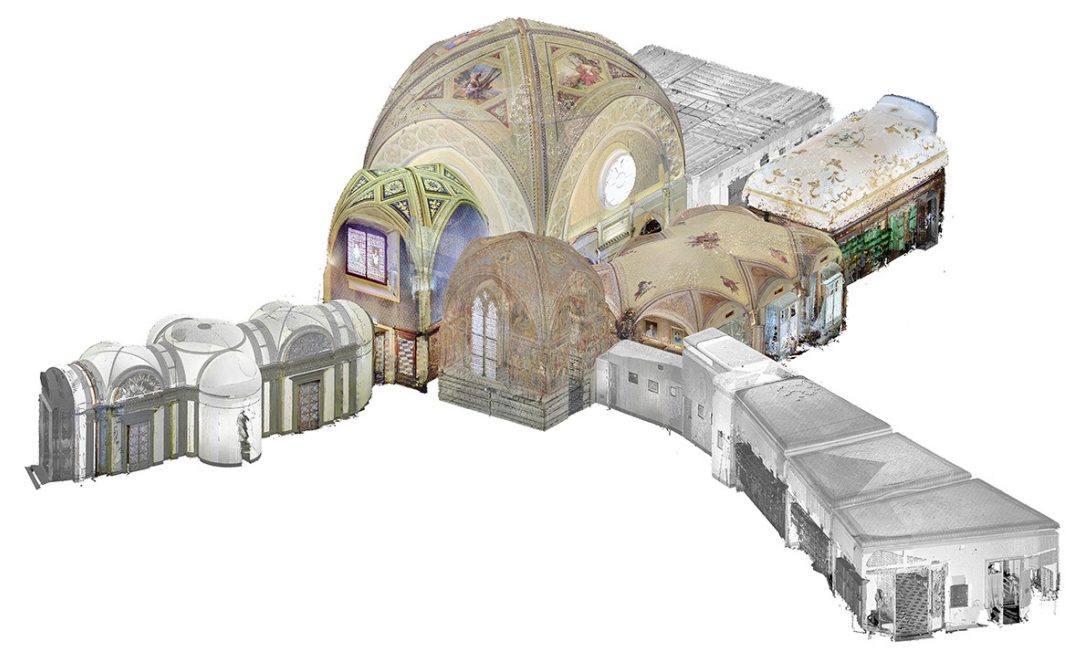




\section{The Historical-architectural evolution of the pharmacy}

The Pharmacy of Santa Maria Novella was founded in 1612 [Alphandery, Ciappi 20 I7, pag. 29] and is the synthesis of a centuries-old evolution of a series of buildings closely connected to the famous monastic complex and the city. Located where the aromatic laboratory of the Dominican convent had the place since the thirteenth century, the pharmacy is part of the monumental chapel of San Niccolò, built between I332 and I 334, thanks to generous funding from Dardano di Tingo Acciaioli, allocated to thank the Dominican friars who had healed him [Alphandery, Ciappi 2017, pag. 12]. Between 1385 and 1405 the Acciaioli family financed the frescoes in the sacristy with scenes from the Passion of Christ attributed to Mariotto di Nardo [Alphandery, Ciappi 2017, pag. 14]. In the eighteenth century, the premises of the ancient apothecary overlooking the large cloister were renewed, with the decoration of the vault in the rocaille style and the creation of a decorative frieze to dampen the austerity of the wall furnishings and the counter and to recall the golden stuccos representing figures grotesque ceiling. The Green Room, annexed to the pharmacy in 1542 as a laboratory, was transformed into a hall for the reception of distinguished guests and furnished in a directorial style. This room contains the portraits of the director friars, starting from Angelo Marchisi, who opened the business to the public in 1612 . In the portrait of the apothecary Tommaso Valori (1756-1825) [2], who bought the apothecary in 1813 from the French government, there is the plan of the pharmacy. He developed a project for the transformation of the chapel of San Niccolò from a warehouse to a salesroom and the construction of a new larger entrance on via Della Scala. In 1814 , with the revocation of the suppression of ecclesiastical goods imposed by the Napoleonic government, the church and the convent of Santa Maria Novella returned to the friars and in 1817Valori donated the pharmacy to the Dominican fathers, however maintaining their direction until I823. The project developed by Valori was implemented by his successor, the new apothecary Friar Damiano Beni ( 1806- | 869), who began work in 1847, under the direction of the architect Enrico Romoli [6]. The project involved a radical redistribution of the internal environments, closing the entrance from the cloister, dividing the spans of the chapel of San Niccolò into two separate rooms, and merging the Gothic and Rococo style of the pharmacy, the neoclassical and neo-Gothic one of the new premises [3]. From the new entrance in neoclassical style (fig. 3), consisting of an atrium with a staircase with lonic order decorations in pietra serena, you enter a vaulted entrance hall that leads to the sales hall in neo-Gothic style, frescoed by Paolino Sarti with motifs representing the four continents to underline the international importance of pharmacy and the exotic origin of raw materials [4]. The

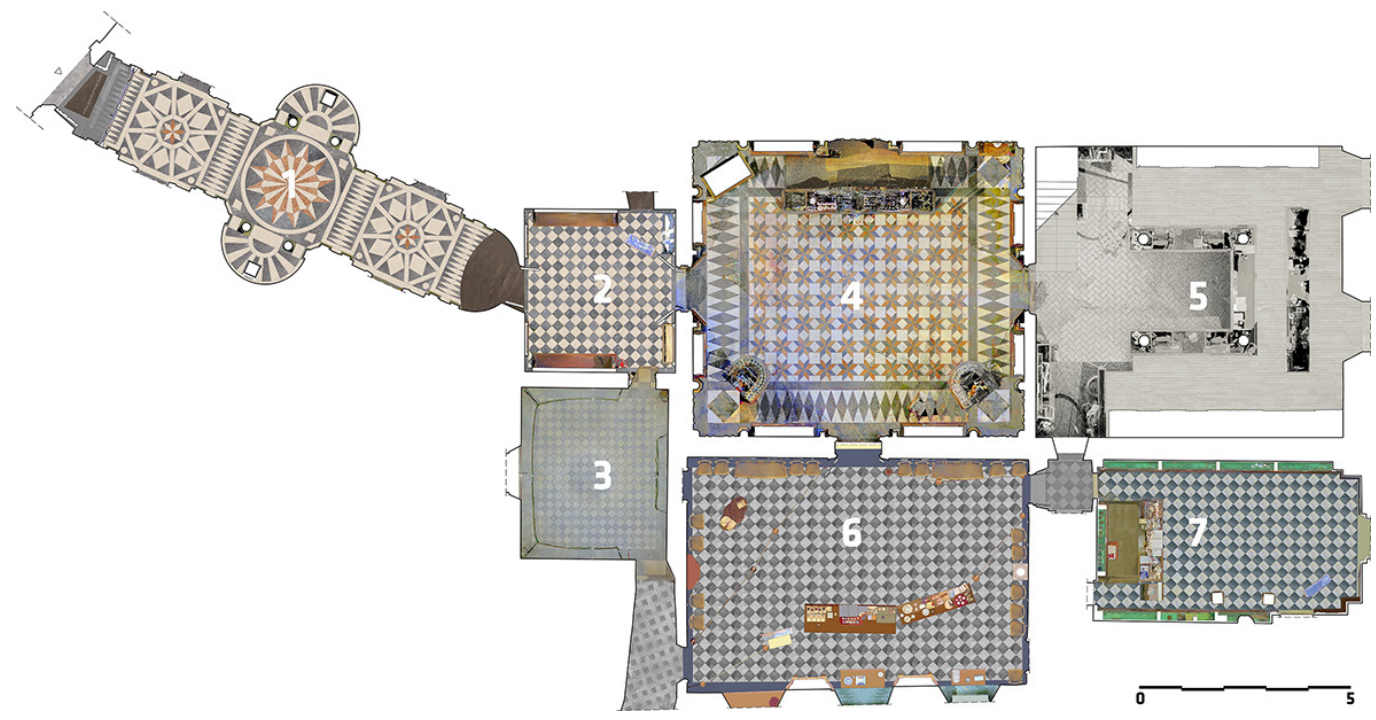


pharmacy, as it appears nowadays, is the result of an important restoration intervention that took place in 2012. The two laser-scanner survey campaigns, carried out in 2019 and 2020, produced a colored point cloud of the entire pharmaceutical complex, but the virtual tour concerns only the environments covered in this paragraph.

Fig. 3. Longitudinal section of rooms 1, 2, 4 and 5. The 2D drawing were created during the Laboratory of Architectural Survey of Prof. Stefano Bertocci. Thanks to the students: Sara Bertoncini, Sara Biagini, Elisa Bianucci, Chiara Bovagnet, Francesco Capacci, Bianca Sofia Cardelli Irene Cardelli, Valeria Chiariello, Romina Columbu, Michele Di Puorto Marco Duranti, Sara Marchesini

Francesca Muzzi.

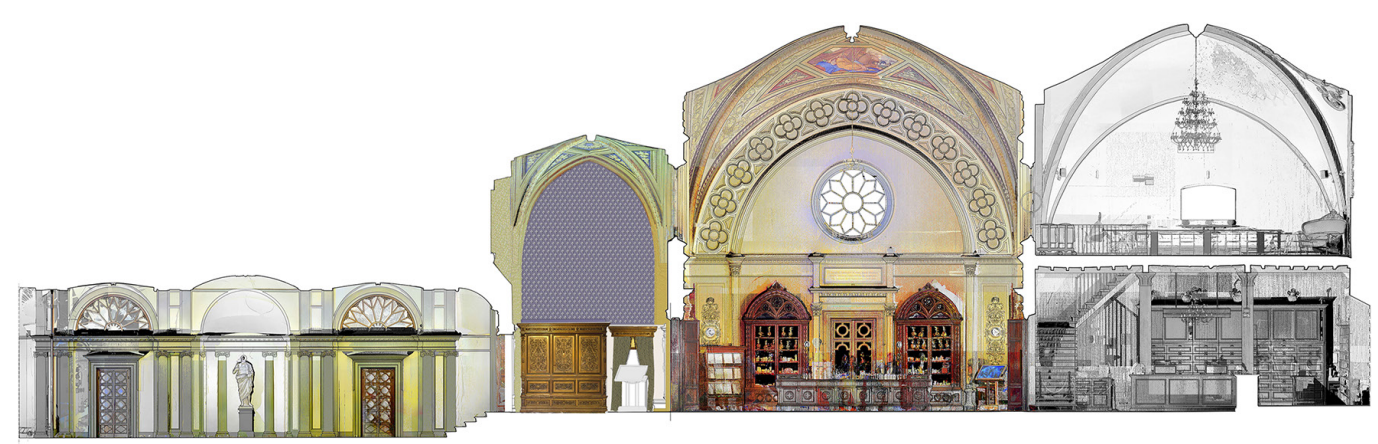

The virtualization of the point cloud

The aim of virtual reality is to simulate a real and existing environment through new technology means to give the users the feeling of being inside that contest, an immersive experience. Nowadays the term has also taken on a wider meaning and indicates all those applications that allow some level of interaction with the described environment, even when the simulation is not total but involves only some senses. The idea of the creation of artificial environments it is not properly linked to the architectural world, it was experimented for the first time in 1962 with the Sensorama, a mechanical instrument design by M.Heiling with the purpose to involve not only sight and hearing, but also the sense of smell and touch of a spectator who was observing films made especially for that machine.

The virtual reality discussed here was born to give the opportunity to create 3D scenarios and landscapes in which a subject has the impression of moving. The point of this research is to virtualize the environment surveyed in order to create new opportunities and new tools in the study and knowledge of the built heritage. Through interactive virtual tours, the user is able to get a complete picture of the building and has the opportunity to test personalized training experience in which he chooses what to view and what information to extract according to his personal interests, requiring the active participation of the user. With the technologies currently available, the enjoyment of interactive virtual visits can take place in many ways. However, creating a virtual environment is not an easy or instant operation and requires time, precision and specific technical skills. For the realization of this virtual environment has been used the Unreal Engine Software, produced by Epic Games, that allows us to bring the Farmacia SMN in an alternative virtual environment and to offer a format that can be reused in any other related context. Unreal Engine is one of the most established Open Source software on the market for the creation of Real Time Rendering and virtual environments, in ongoing development not only to perform the original functions related to the world of gaming, but now offering the most detailed virtual experiences. Currently the fourth generation of the engine, UE4, version 4.24.2, is available. The usual process to follow to use the software is to export the models in .FBX format from Maxon Cinema 4D or other 3D modelling software and import them into the Content, after an intermediate step of optimisation of the polygons and points that characterise the model, which makes the interactive experience more fluid. Lidar Point Cloud, the new plug-in within UE4, completely revolutionizes the workflow until now followed for the digitization and virtualization of the 
architectural asset as it was developed to help users to import, visualize and process point clouds acquired by laser scanning devices (fig. 4).

The main features concern the supported file format, such as ASCII (TXT, XYZ, PTS) and LAS, and the ability of uploading a large amount of datas, recognizing the different types of point coloring (such as RGB, Intensity, Elevation, Classification) and the ability to manage the imported point cloud in all its complexity. Inside the Details panel of the point cloud, the first step is to set the amount of points we want to visualize in the scene, obviously a high number of points allows a more truthful and detailed representation of the architecture but it involves a substantial increase in the number of elements and then the subsequent rendering time that could cause a slowdown even during the virtual reproduction, due to the decrease of FPS (frames per second) inside the scene, which should not be less than 90 to ensure a pleasant and fluid immersion in the virtual (fig. 5).

When we get close to a Static Mesh we placed inside the level, which in our case is the point cloud itself, it could be useful to have a detailed view of it. However, it is not necessary for this level of detail to remain once we move away, if it only covers a few pixels on the screen. UE4 solves precisely through the use of Level of Details or LODs, the problem of the weight of the scene caused by the amount of objects present in it. In addition to the amount of points, the next steps concern the setting of their size and shape; it is therefore clear that being able to modify the point clouds within the final visualization software without having to use specific software such as Autodesk Recap or CloudCompare is a huge advantage in terms of timing and workflow complexity (fig. 6). Once the various steps have been completed and the application created, the visualization of the virtual environment takes place through the use of viewers, such as Oculus Rift S, Oculus Quest or HTCVivepro. The VR viewer can be replaced by a VR support for smartphones, which thanks to its low cost, makes it accessible to a wider audience, even if considerably at the cost of the quality of the proposed experience.
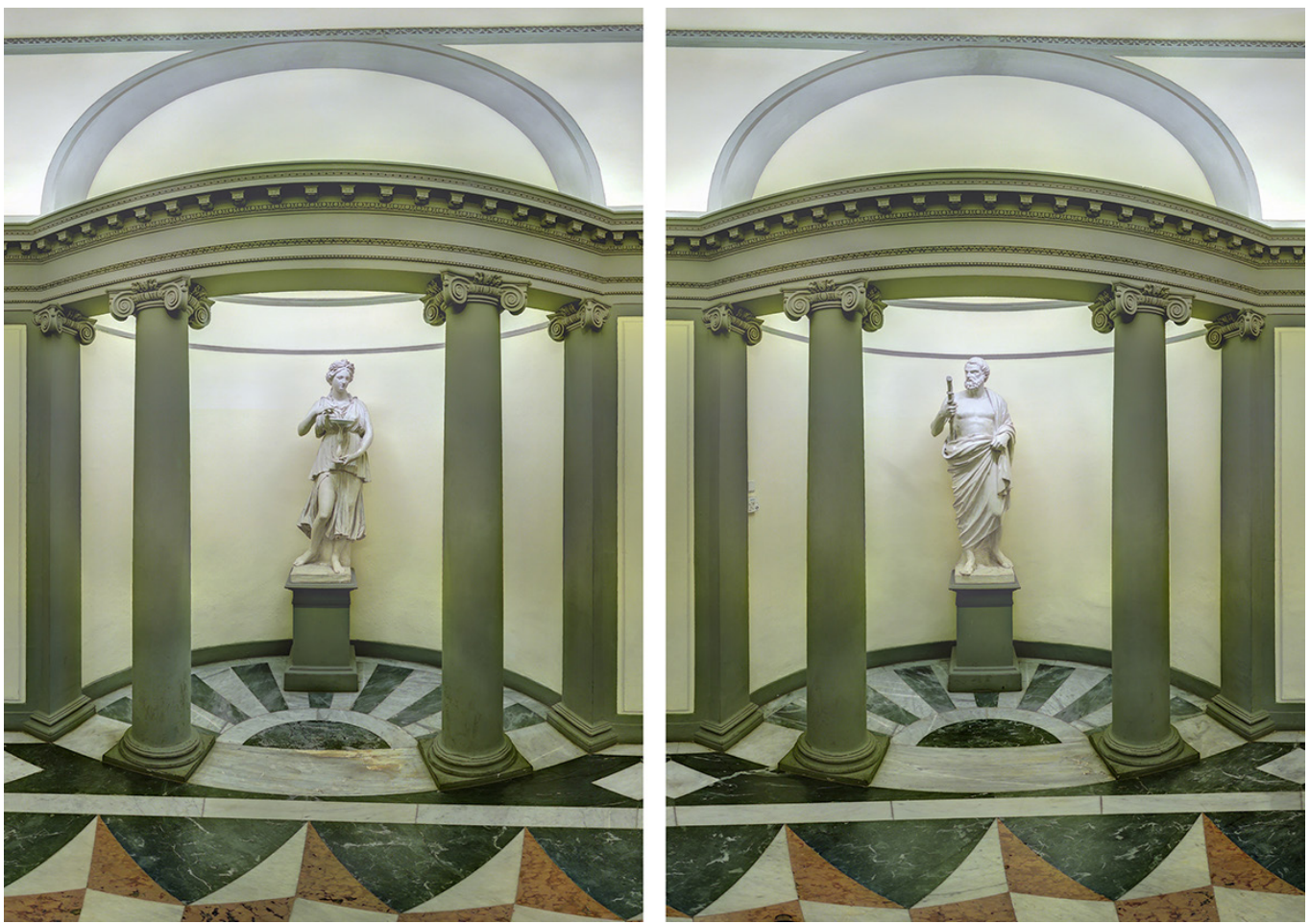
At the end of the research, it is worth remembering that the process aims to create a complete product, integrating the main data (historical analysis and survey of the architectural heritage), the simplifying of the virtualization process, the use of the VR experience in the cultural heritage and the creation of a virtual temporary reality. This registers the conditions of the building at the time of the survey and makes it accessible and tangible in the future, creating a chronological archive of its conditions and its temporal evolution. The archiving of Cultural Heritage widens the possibility of analysis and study of the object with the sensorial increase of the relationship with it and with the intention of creating a prototype, a methodology applicable not only to this theme, but to all the existing architectural heritage. The research sectors involved in this process of creating new exploratory paths are many and the results are appreciable in the reconstruction of landscapes, cities, monuments and works of art. An environment is created that becomes a dynamic place where man and architecture interact on the basis of perspectives linked to the past and present, monumental complexes are recreated in their original appearance, with interesting developments in the diagnosis of the state of deterioration and restoration, and a new way of investigating and classifying the architectural heritage is offered.

Fig. 5. The compartment of the ancient apothecary. The rocaille vault was decorated in the eighteenth century with grotesque motifs in gilded stucco.

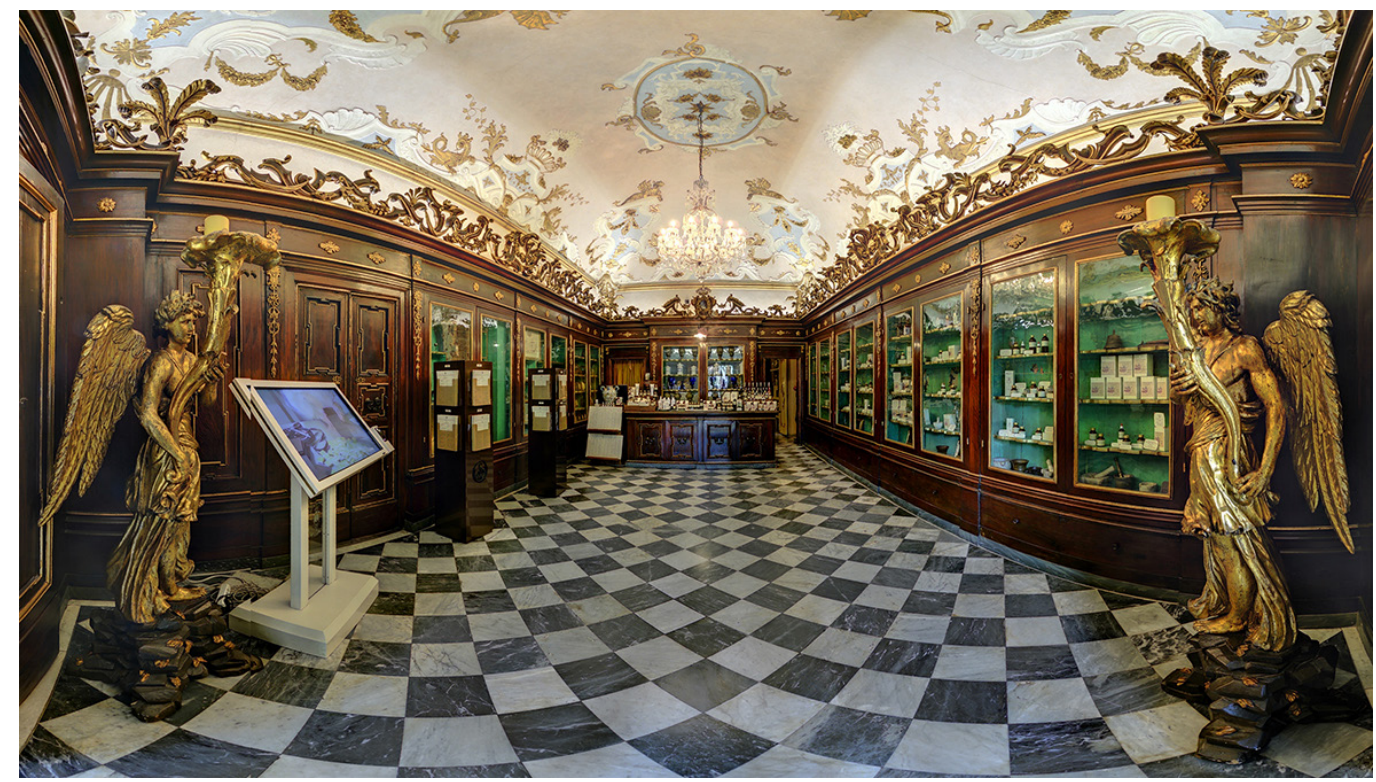

\section{Conclusions}

The large amount of physical and digital data acquired during the survey campaigns constitutes an archive of information that risks being left unused. The purpose of this work is to present the first results of a process that aims to develop a methodology for the management and use of point clouds, which constitute databases rich in metric and morphological information. Through the establishment of a virtual tour within the 3D model, it is possible to enter the historical information and documentation collected during the research to develop dissemination tools of the results that entail an optimization in the use of data without the need for further stages of modeling and rendering. The data is rendered through an easy-to-use interactive interface, exploiting the descriptive potential of the point cloud which in itself constitutes an important archive of metric data which in the discretization of 2D representation necessarily loses content. These tools are less appealing to the user than the interfaces obtained through NURBS or mesh modeling, accentuating the functional and didactic aspects of the models and the need for greater reliability between the real object 


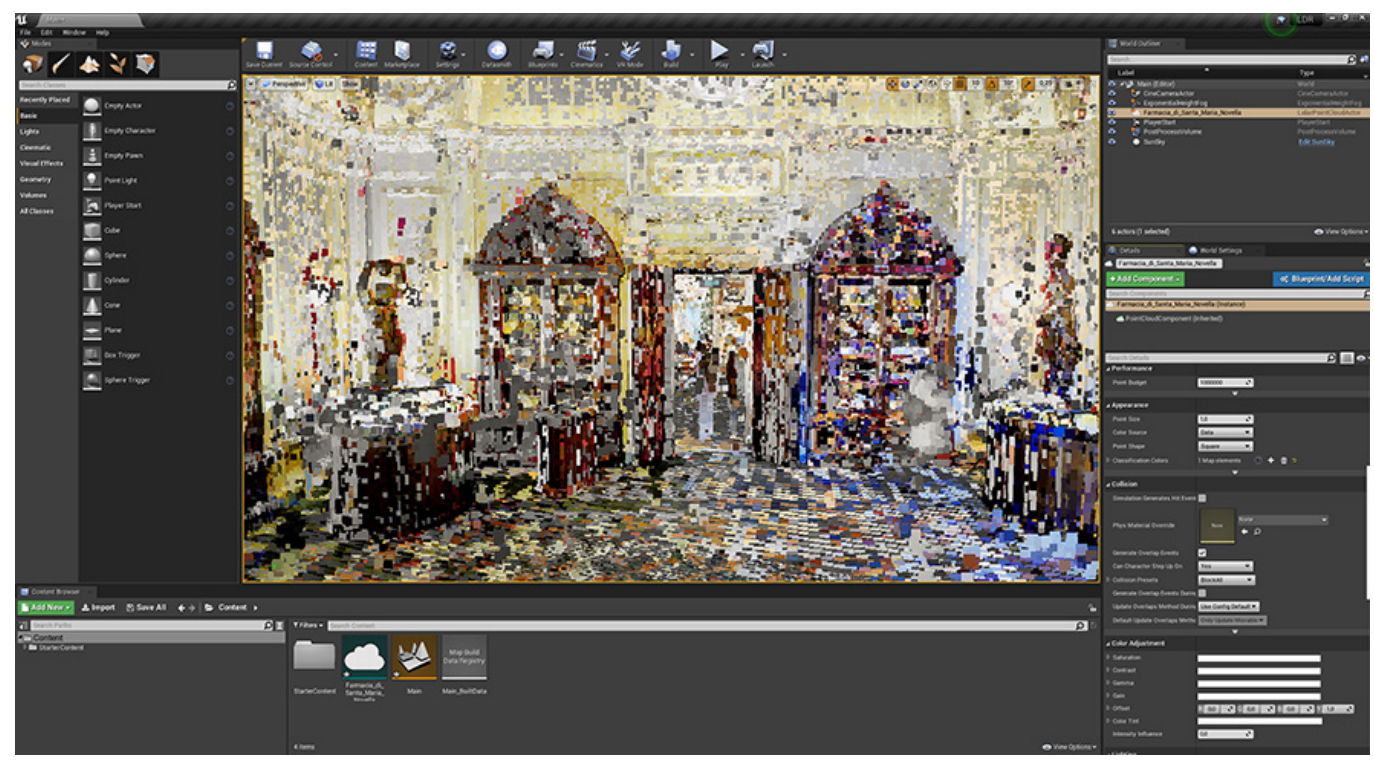

and the virtual environment. The risk that is run through the virtualization of the heritage is to attract the attention of less and less critical users. The virtual experience must not replace or imitate the real experience but must be a cultural experience in itself, which allows the user to acquire information otherwise inaccessible in physical reality.

Fig. 7. On the left: setting Cloud settings; on the right: the point cloud displayed in Lidar Point Cloud.
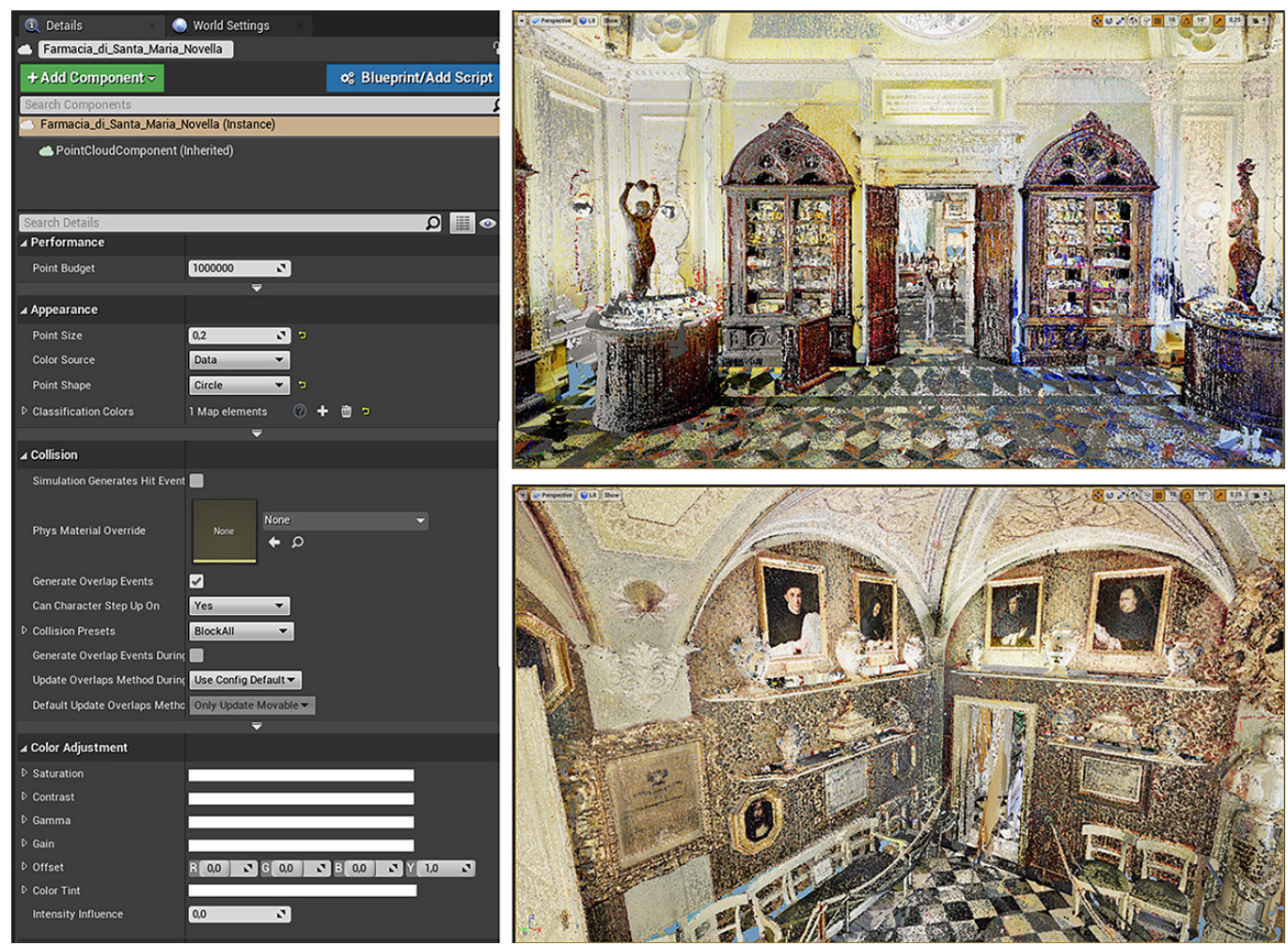


\section{Notes}

[I] Federico Cioli is responsible for drafting paragraphs I, 2, and 4. Ylenia Ricci is responsible for drafting paragraph 3.

[2] Recognized as a pharmacist by the Arte dei Medici e degli Speziali, Valori was the director of the workshop in the Napoleonic period, and thanks to him he remained open to the public thanks to the scientific value of the production.

[3] From the same period in Italy we find examples of this mixture of styles in the Casa di Ignazio Villa (I 847), in Florence and the Caffè Pedrocchi (183|-1839) in Padua.

[4] The position of the current counter, located on the left concerning the entrance, is the original one. The new entrance was built later than the new salesroom, maintaining access from the cloister for a few years.

\section{References}

Alphandery Benedetta, Ciappi Silvio (20 I7). Officina Profumo Farmaceutica di Santa Maria Novella. Milano: Silvana Editoriale.

Bertocci Stefano, Cioli Federico, Bordini Eugenia (2018). Virtual models for the valorisation and promotion of the business heritage in the historic centre of Florence. In DisegnareCon, Vol I I, No 2 I.

Cioli Federico (2019). I luoghi del commercio: tra realtà e rappresentazione. In Belardi Paolo (a cura di). Riflessioni. L'arte del disegno. Il disegno dell'arte. Atti del $41^{\circ}$ Convegno Internazionale dei Docenti delle Discipline della Rappresentazione. Perugia, 19-2I settembre 20 19. Roma: Gangemi Editore, pp. 553-560.

Mancini Gabriella, Giovannini Sandra (1994). L'Officina Profumo-Farmaceutica di Santa Maria Novella in Firenze sette secoli di storia e di arte. Roma: Chitarrini.

Verdiani Giorgio, Ricci Ylenia, Pasquali Andrea, (2019a). Mito, pietra, spolia e storia, frammenti di indefinito da Costantinopoli a Istanbul. In Conte Antonio, Guida Antonella (a cura di). ReUso. Patrimonio in divenire. Conoscere, valorizzare, abitare. Matera 2019. Roma: Gangemi Editore, pp. 1203-1214.

Verdiani Giorgio, RicciYlenia, Pasquali Andrea, (2019b). Ancient remains from the Roman Istanbul: a transmutation from stone to digital. In C. ten Busch, C. Kassung, J. Sieck (eds.). Proceedings of KUI. Kultur und Informatik: Virtual History and Augmented Present. Glückstadt:WWH Verlag Wemer Hiilsbusch, pp. I5-28.

Verdiani Giorgio, Ricci Ylenia, Pasquali Andrea, (2019c). A petrified petrifying eyesight: a story for the Medusa's heads. In W. Börner, S. Uhlirz (eds.). Proceedings of the 23rd International Conference on Cultural Heritage and New Technologies. 20I8, Wien, pp. I- I5.

\footnotetext{
Authors

Federico Cioli, Università di Firenze, federico.cioli@unifi.it Ylenia Ricci, Università di Firenze, ylenia.ricci@unifi.it
}

To cite this chapter: Cioli Federico, Ricci Ylenia (2020). L'officina profumo-farmaceutica di Santa Maria Novella. Dalla nuvola di punti alla realtà virtuale/L'Officina Profumo-Farmaceutica di Santa Maria Novella. From the point cloud to the virtual reality. In Arena A., Arena M., Brandolino R.G. Colistra D., Ginex G., Mediati D., Nucifora S., Raffa P. (a cura di). Connettere. Un disegno per annodare e tessere. Atti del $42^{\circ}$ Convegno Internazionale dei Docenti delle Discipline della Rappresentazione/Connecting. Drawing for weaving relationships. Proceedings of the 42 th International Conference of Representation Disciplines Teachers. Milano: FrancoAngeli, pp. 1958-1973. 